\section{Inclusive Service Experience Management: a Framework from the Perspective of People with Visual Impairment}

\author{
Bibiana Conrad ${ }^{1}$ \\ Graziela Dias Alperstedt ${ }^{1}$ \\ Aline Regina Santos ${ }^{1}$ \\ ${ }^{1}$ Santa Catarina State University, Postgraduate in Business \\ Administration Program, Florianópolis, Brazil
}

Received on

08/06/2018

Approved on

$01 / 16 / 2019$

Responsible editor:

Prof. Dr. Susana Costa e Silva

Evaluation process:

Double Blind Review

\begin{abstract}
Purpose - This article proposes a framework for service experience management from the perspective of people with visual impairment.

Design/methodology/approach - The study is based on design science research and characterized as qualitative, using its respective methodological framework for technical collection and analysis. The combination of Booms and Bitner's (1981) theory of the 3 Ps of Service Marketing (physical evidence, people, and processes) with the three propositions of Bolton et al. (2014) formed the backdrop to this proposal.
\end{abstract}

Findings - Based on 32 subcategories of analysis connected with Physical Evidence, Service Cycle, and Personal Interactions, besides 12 subcategories created to highlight the service segment cited by the interviewees, the study shows a high degree of unpreparedness in the service offer when it is consumed by people with visual impairment. Lack of empathy and communication were the most expressive problems in the interviewees' statements.

Originality/value - The proposed framework can be used as a brainstorming, planning, or check list tool for current or new services in existing businesses as well as for the creation of a new business from scratch. All categories are related to each other, which means that the consumption profile for the service will directly impact on what kind of experiences could be provided, how the physical evidence needs to be thought out; what the standard service flow is like, and which options could be considered as a customized service.

Keywords - Inclusive Service Experience Management; Visual Impairment; Design Research.

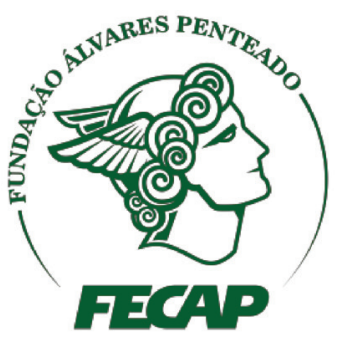

Review of Business Management

DOI: $10.7819 /$ rbgn.v21i5.4027 


\section{Introduction}

Being different and becoming memorable to consumers and partners is one of the great challenges for managers in the service industry, as ways of thinking and consuming are constantly evolving and often aspects that were once perceived as differential are today considered parity attributes. Seeking to build a global view on the scientific research on services and to support businesses in order to set them apart in the market, Ostrom et al. (2010) and Ostrom, Parasuraman, Bowen, Patricio, and Voss (2015) identified the greatest gaps between the research priorities and current knowledge evidenced by scientific production.

These studies englobe service researchers' perspectives throughout more than 37 countries and show that "improving well-being through transformative services" is the second theme with the greatest gap between the importance of a social and economic issue vs. the current knowledge about it (Ostrom et al., 2015), "Stimulating service innovation" and "Enhancing the service experience" research subjects are in fourth and seventh place in these studies, respectively. Thus, there is a need to promote studies focusing on empathy for the construction and management of the service experience.

It is important to analyze how customers interact with the service by considering the environment where it is experienced, the processes throughout the service delivery, and the personal interactions throughout the experience (Bolton, Gustafsson, McColl-Kennedy, Sirianni, \& Tse, 2014; Zeithaml, Bitner, \& Gremler, 2014). However, from which perspective should service experiences be looked at when consumers are visually impaired?

According to the World Health Organization (2014a), visual impairment affects more than 285 million people worldwide, and $90 \%$ of the cases are concentrated in poor or developing countries, as is the case of Brazil. The 2010 Census data from the Brazilian Institute of Geography and Statistics (IBGE, 2010) corroborate this, noting that visual impairment is a condition experienced by more than 35.7 million people (19\% of the population) in the country.

These results show that the reality of part of the world's population when using services is quite different from that of the majority, which leads it to being questioned whether the instruments adopted to manage the service experience encompass the needs of visually impaired people. This is especially relevant within the context of the Brazilian marketplace, where the Brazilian Law on the Inclusion of Persons with Disabilities n. 13,146 (2015) was recently sanctioned, requiring business owners to ensure and promote conditions of equality on their premises, while the same time only a few studies have so far focused on service experience management by embracing the perspective of visually impaired people. Considering that the services sector has been responsible for more than $60 \%$ of Brazil's GDP in the last two decades (IBGE, 2015), such studies into new ways of managing services have the power to create the utmost positive impact if they are followed by actions that solve real consumers' problems.

In order to mobilize this discussion to support not only business owners but also academia, contributing to a reduction of gaps in the scientific production between social and service experience innovation paradigms, this article proposes a framework for service experience management from the perspective of people with visual impairment, analyzing aspects related to physical evidence, the service cycle, and the personal interactions in services.

The study behind this proposal was based on design science research and characterized as qualitative, using the respective methodological framework for technical collection and analysis. The framework proposition oriented toward understanding and discussing the service experience phenomenon corroborates studies such as those of Nasution, Sembada, Miliani, Resti, 
and Prawono (2014), Tsiros and Parasuraman (2006), and Verhoef et al. (2009). As underlined by Verhoef et al. (2009), a framework proposition is indicated when there is a conceptual shortage, as observed in this case, particularly when the theme concerns the service experience for visually impaired people.

\section{Literature Review}

\section{I Visual impairment and service experience}

Brazilian Decree No. 5,296 (2004) considers visual impairment to be characterized according to the visual acuity of each person, where blindness is diagnosed when the person's acuity in their best-seeing eye is equal to or less than 0.05, even with optical correction; while low vision is defined when visual acuity is between 0.05 and 0.3 in their best-seeing eye, even with optical correction. The sum of the visual field measurements in both eyes is also considered and if it is equal to or less than 0.6 the person is diagnosed with visual impairment. It should be noted that the term severe visual impairment encompasses cases of blindness and low vision and this is the group focused on in this article.

"People with visual impairment have not been widely studied as a consumer group," according to Yu, Tullio-Pow, and Akhtar (2015, p. 122), even though there is a significant percentage of visually impaired consumers worldwide, according to the WHO (2014b). This is evident from a bibliometric review on the subject carried out in the Scopus, Science Direct, Spell, EBSCO, and Emerald (2015) databases, focusing on the Business, Management, and Accounting fields.

In terms of international research on customer experience from the perspective of visually impaired people, it is possible to find studies focused more on how hardware and physical experience could be improved through assistive technology (Ando, 2008; Jutla \& Kanevsky, 2009; Moayeri, Mapar, Tompkins, \& Pahlavan, 2011; Sandnes et al., 2012), as well as how digital interaction with visually impaired customers is enhanced by accessibility ( $\mathrm{Yu} \&$ Parmanto, 2011; Youngblood, 2013; Zia \& Fatima, 2011). Particularly regarding on-site service experiences, Baker (2006) and Baker, Stephens, and Hill (2002) are a reference in the United States market. The authors make some assumptions, such as: the market can provide the benefit of independence for visually impaired consumers; visually impaired consumers have a well-defined and different set of needs to people with other disabilities, and this can be used to create managerial tactics; and consumers with visual impairment claim that they are labeled due to their disability and this leads to misunderstandings.

Yu et al. (2015) are also a reference regarding the main challenges encountered during retail shopping experiences in Canada and these can be separated into aspects related to tangible service factors such as access and mobility within the store, use of distinctive colors, legibility of labels, signage inside the store, and receipts, lighting, and furniture layout, among other things, and intangible service factors, such as interaction with service providers and the checkout process.

Although most cases of visual impairment are concentrated in poor or developing countries, as previously mentioned as being the case of Brazil (WHO, 2014a), only a few studies cover the issue of visual impairment and its relationship with some elements of the service experience within the context of the Brazilian marketplace. Dischinger and Jackson $(2006,2012)$ and Souza and Moraes (2013) evaluated accessibility in public places. For Dischinger and Jackson (2006), three elements are fundamental to working on urban scenarios: 1) creating a channel of communication with users so that they are involved at all stages; 2) understanding that the technical knowledge of engineers and architects, for example, should be complemented with different visions to generate innovative solutions, given the complex nature of this problem; and finally, 3) understanding the political and economic context of the associations 
and public institutions involved in the process is a key success factor.

Faria and Motta (2011) and Faria and Silva (2012), on the other hand, specifically searched for experiences in leisure and food services. The former addressed barriers to the consumption of travel packages, noting that there are intrapersonal, interpersonal, and structural restrictions for consumption by the visually impaired. The 2012 research studied how to improve the restaurant experience, including attributes such as menu, attendance, ambience, table format, waiter access, table turnover, location, and food.

Some elements regarding the scenario, processes, and people are part of this set, reinforcing the idea that customers perceive the experience in a holistic way. This can also be seen in the study by Pinto and Freitas (2013), who addressed the purchasing experience for people with visual impairment in Minas Gerais. The authors state that the consumption experience has a symbolic meaning of belonging, autonomy, and hedonism.

There has been an unquestionable contribution from both international and Brazilian papers to the construction of the framework proposed in this article, which intends to fill a gap in the scientific production on service experience innovation and the promotion of wellbeing, applied to a developing country context. Only 12 researchers (3.6\% of the total) involved in the Ostrom et al. (2015) survey are from Latin America, evidencing a massive opportunity to take the scientific production in this field to the next level, not only covering the reality of emergent marketplaces, but also creating the chance to build parallels between the constructs for service experience management in developed and poor countries.

As previously mentioned, people with visual impairment have not been widely studied from a business perspective, especially in the wider context of customer experience management. For this reason, the following topics aim to present customer experience and service marketing theories in a broader manner, considering that the current scientific production focused on people with visual impairment does not have concise theories regarding these topics.

\subsection{Customer experience management}

The term "customer experience management" is relatively new to academia, although it is intrinsically linked to the field of service studies. In the bibliometric review carried out in the Scopus database for this study, the data show that although the first publications on the subject are from 1982, an upward trend in publications only began in 2004. Levy (1959, 1963) and Levy and Czepiel (1974) were pioneers of studies on the relationship between lifestyle and consumption of products and their symbolic aspects and inspired the works of Hirschman and Holbrook (1982), Holbrook and Hirschman (1982), as well as other scholars that have addressed the hedonic consumption of products and became some of the initial references in the area of experience management. Additionally, Shostack's (1977) work was a milestone for the beginning of the studies on the impact of intangible aspects and the need to broaden the marketing vision, hitherto focused on in product studies. Her work has influenced Bitner (1992), Normann (1984), and Parasuraman, Zeithaml, and Berry (1988), among others, who have become references for both the service and experience management fields.

Some authors defend the idea that experience management needs to be viewed more as a longitudinal process linked to the company's relationship with consumers than as the result of an isolated action (Grönroos, 1998; Verhoef et al, 2009). This relationship, in turn, is established in any interaction between the customer and the company during the service delivery process, either by electronic or physical means, containing an associated product or only the service itself (Bolton et al, 2014; Lovelock, 1994; Meyer \& Schwager, 2007). 
Furthermore, there is something beyond the interaction between the customer and the service provider, which makes the moment a memorable experience (Gentile, Spiller, \& Noci, 2007; Meyer \& Schwager, 2007; Norton \& Pine, 2009; Pine \& Gilmore, 1998; Verhoef et al, 2009). Dubé and Le Bel (2003) consider four dimensions for experience management: physical (or sensory), as an effect of pleasant sensations induced during the experience; social, which is the result of interaction or lack of interaction with others (pleasure in solitude); emotional, connecting pleasure to feelings, ideas, and mental images; and intellectual, as a consequence of the appreciation of the complexity and subtleties of things around the consumer.

Gentile et al. (2007) divide experience management into six dimensions: sensorial, formed of experiences that involve the five senses and how they awaken aesthetic pleasure, stimulation, satisfaction, and a sense of beauty; emotional, which is related to mood, emotions, and feelings, and generates an affective relationship with the company; cognitive, which involves problem solving and creativity; pragmatic, where the experience is the result of usability; lifestyle, which includes experiences that work by affirming individual values and beliefs; and relational, which involves the relationships and social context of a community.

The details that make a customer experience unique affect the individual in a subjective way and it is difficult to control how the customer will interpret the stimuli present in the service delivery (Gentile et al, 2007; Meyer \& Schwager, 2007; Norton \& Pine, 2009). For this reason, Norton and Pine (2009) argue that a new mindset is critical for those who wish to work with experience management. For them, rather than investing in reducing task time or spending time with each customer at each meeting point, a trained manager should focus on understanding which sequence of events creates the most value for the customer and how the time spent on each task can enhance this value creation individually.
Within this logic, Lusch and Vargo (2014) argue that the customer experience cannot be designed as a one-way street, but rather cocreated through customer interactions with the various elements present in the service encounter. Thus, clarity about the intention of the company behind the service creates a purpose, and this is a differentiating point at the time of interaction, capable of dramatically changing the experience with the brand (Norton \& Pine, 2009).

Other studies seek to aid the understanding of the service experience by proposing conceptual frameworks. One of the first conceptual models which introduces variables related to experience was proposed by Pine and Gilmore (1998). In a comprehensive way, the authors present four scenarios of experience that consider the type of client involvement (active / passive) and the environment in which the client is involved (absorption / immersion).

Years later, some publications analyzed the experience using more specific approaches, as observed in that of Verhoef et al. (2009). In this paper, the authors present the variables that influence the strategic management of the consumer experience. It presents variables of company responsibility, such as the physical environment, brand, and service interface, and others related to the consumer, such as previous experiences, situation, and consumer moderators.

It is worth mentioning the conceptual framework proposed by Nasution et al. (2014), in which the authors base their approach on the customer's journey and delineate the experience from a five-tiered combination that begins with the needs of the consumer and ends with a change in the consumer's behavior. The layer of experience signals the importance of experiences that stimulate emotions and delight, aiming to transform the experience into something memorable.

Given the richness of concepts, it is not surprising to see that there is not a concise conceptual framework and these dimensions are often overlooked in service management, especially when managers do not have access to tools that facilitate the inclusion of these theories in the company's everyday life. 
To guide managers in providing memorable experiences, Bolton et al. (2014) suggest care with some details in service providing. The assumptions advocated by Bolton et al (2014) will be used in this research as a reference for the analysis of services experienced by people with visual impairment, since their ontology and epistemology are aligned with the view adopted by the researchers of this article, and so it was one of the works on which the proposed framework is based. The approaches are: 1) design and deliver experiences with a "human touch," primarily seeing the customer as a human being with unique needs; 2) create experiences that evoke emotion through sensory experiences with tangible elements or through a customized service, for example; and 3) design and deliver experiences with a "human touch" that evoke emotion. This combination of previous approaches can be achieved by creating opportunities for empathic personal interactions, redesigning the service to be co-created by consumers, which could be directly connected to theories about personal interactions in services, as defended by Booms and Bitner (1981).

Furthermore, the first two assumptions advocated by Bolton et al. (2014) also create an opportunity to relate these recommendations to Booms and Bitner's (1981) work concerning the Ps of service marketing, considering that small details make a big difference when used to ensure that the experience is human-centric at every customer's meeting point with the company, which could be associated with theories related to the service cycle. Also, sensory experiences created with tangible elements or through a personalized service to evoke emotions could be linked to theories about physical evidence in services. The following topic intends to clarify these points.

\subsection{Physical evidence, service cycle, and personal interaction: The triad of experience}

One of the most striking and distinguishing features of services in comparison to products is intangibility. Services that are deemed "pure" are primarily intangible and dependent on trust to assess quality, whereas "pure" products' tangibility makes this analysis easier and more objective (Shostack, 1977). Thus, physical evidence plays a strategic role in service experience management, because it aims to reduce the degree of intangibility and works as one of the supports to evaluate the quality of the experience, besides being a tool of orientation, socialization, or differentiation of the company. This evidence can be divided into three categories: (1) outside the establishment; (2) inside the establishment; and (3) other tangible evidence (Bateson \& Hoffman, 2001).

For Bitner (1992), physical aspects have the power to influence the consumers' perception regarding the corporate image and its purpose. Two further aspects highlighted by this author in her model called Servicescape are that customers perceive the environment holistically and that this has an effect on employees.

The service cycle is closely linked to the "processes" item, because "services are inherently relational. A service encounter in which a customer, for example, is a restaurant goer or makes a phone call is a process (Grönroos, 2009, p. 7). Thus, service delivery can be seen as a process with a continuous flow of interrelated experiences, which is a challenge for many managers who typically visualize it in a fragmented way according to the responsibilities of each sector of the company (Albrecht, 1992; Gianesi \& Corrêa, 2010; Verhoef et al, 2009).

The chain of events is connected by points called the "moments of truth" (Normann 1984, p. 89), which are, according to Albrecht (1992, p. 27), "any episode in which the customer is in contact with any aspect of the organization and gets an impression of the service quality." It should be noted that the service cycle must be created using the customer's point of view. Thus, every moment of truth represents a stage of the service experienced from the perspective of the consumer.

It is possible to say that within the service cycle there are critical moments of truth (CMOT), which according to Gianesi and Corrêa 
(2010, p.89) "are those in which service elements affect the perception of the client in relation to their most important evaluation criteria," such as consistency, speed of service, atmosphere of service, access, cost, tangible elements present in service delivery, credibility and security, competence, and flexibility, among others.

Given that the service experience must be viewed in a holistic way (Verhoef et al., 2009), it is important to think about the moments of truth that make up the experience, from initial research to consumption and after-sales, extending to the various sales channels of the company. Attention to these points reinforces the consumer-centric experience message, as well as creating a holistic atmosphere for experience (Bolton et al., 2014).

In addition to the visible elements for the customers, Shostack (1984) brought up the existence of "invisible" elements for the consumer, including aspects such as the company's internal processes. The service blueprint developed by her emerged as an evolution of the service management techniques used until the 1980s. Over time, the Shostack model was improved, as in the works of Stickdorn, Schneider, Andrews, and Lawrence (2011) and Bitner, Ostrom, and Morgan (2008). These authors included into the service cycle physical evidence of the context, considering the interactions of the customers with the front line of the company and its internal support processes. This made the different aspects that fall below the "invisibility line" of the initial model more evident.

Bolton's third assumption (2014) refers to creating opportunities for personal interactions in "empathic" services. The concept of empathy is part of the Theory of Multiple Intelligences that encompasses intrapersonal intelligence, which in turn "depends on central processes enabling people to distinguish their own feelings" (Gardner, Kornhaber, \& Wake, 1998, p.221). Stock and Hoyer (2005) argue that communicating empathically includes listening, feeling, interpreting, and responding. The reflection of this cycle may result in building trust in the established relationship. However, it is worth noting that this cycle applies not only to verbal communication, but also to non-verbal communication, which is equally important (Sundaram \& Webster, 2000).

\section{Methodology}

Following the guidelines for design research and the methodology presented by Aken (2004; 2005), Aken and Romme (2009), Gregor and Hevner (2013), and Lacerda, Dresch, Proença, and Antunes (2013), Figure 1 briefly illustrates the research process, highlighting the compliance with the principles defended by Hevner, Salvatore, Park, and Ram (2004).

For Aken and Romme (2009), design research has the following characteristics: research questions are driven by field problems, as opposed to problems of pure knowledge; there is an emphasis on a knowledge-oriented solution, as the key to solving the field problems; and the justification of research products is largely based on pragmatic validity (does the action based on that knowledge actually produce the intended results?).

Aken (2004) seeks to show that prescription-oriented academic research can effectively achieve academic respectability. In that sense, he believes that understanding a problem is only half way to solving it. The second step is to develop (alternative) solutions. The framework presented in this article addresses this need, creating a broad view on this subject and presenting possible solutions to manage services in an inclusive way based on problems highlighted in the research process. The results shown in the framework combine multiple sources of data, which is a principle of design research. Thus, in addition to descriptive research, the business administration area needs research programs geared toward the development of research products that can be used in the elaboration of solutions for management problems. 


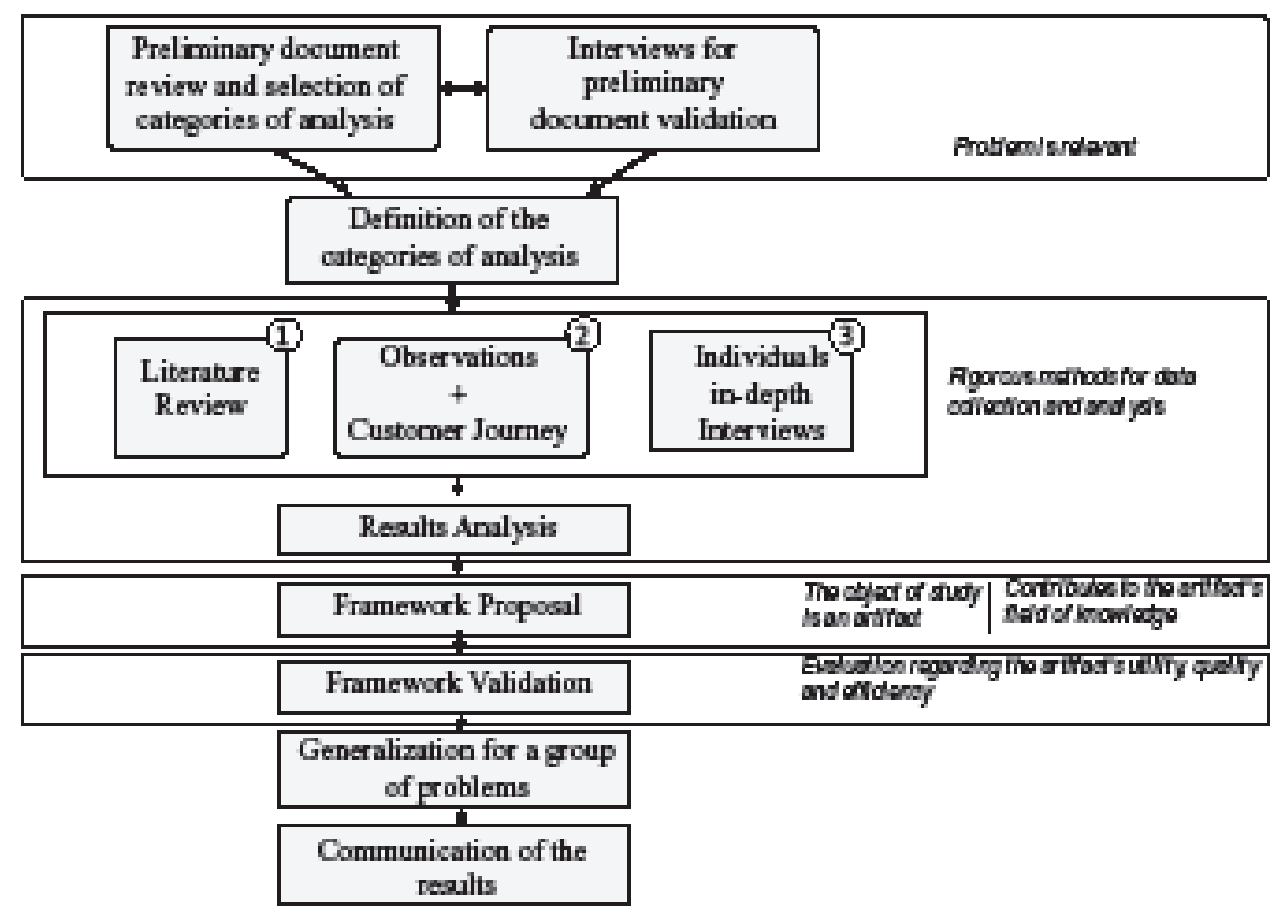

Figure 1. Research Process

Note: Adapted from "Management research based on the paradigm of the design sciences: The quest for field-tested and grounded technological rules," J. E. Aken, 2004; "Management research as a design science: Articulating the research products of mode 2 Knowledge Production in Management," J. E. van Aken, 2005, British Journal of Management, 16; "Reinventing the future: Adding design science to the repertoire of organization and management studies," J. E. van Aken \& G. Romme, 2009, Organization Management Journal, 6; "Positioning and presenting design science research for maximum impact," S. Gregor \& A. R. Hevner, 2013, MIS Quarterly, 37; "Revealing factors affecting strategy implementation in HEIs-a case study in a Brazilian university," D. P. Caulliraux \& T. Spiegel, 2014, International Journal of Management in Education, 8; "Design Science Research: método de pesquisa para a engenharia de produção,” D. P. Lacerda, A. Dresch, A. Proença, \& J. A. Antunes Jr., 2013, Gestão \& Produção, 20.

The first stage of the exploratory phase began with a systematic review of the literature in classic books on service marketing as well as the databases Scopus, Science Direct, Spell, EBSCO, and Emerald. More than 600 articles were selected and analyzed using the EndNote X7 software according to the level of relevance present in the evaluations of each database. The analysis consisted in critically reading and selecting quotes and theories related to the study subject; and the results can be seen in the literature review as well as in the construction of the framework itself. For further results on this matter, the authors recommend accessing the full Msc Dissertation which this article was derived from (Conrad, 2016).

The second stage of the exploratory phase "Interviews for preliminary document validation" - aimed to understand which problems could be approached according to the life experience of people with visual impairment and to understand if it made sense to adopt Bolton's perspective (2014) for research on service experience. For this purpose, semi-structured interviews were conducted with two interviewees, the President and the Technical Manager of the Association for 
the Integration of the Blind in the State of Santa Catarina (ACIC). Both are visually impaired. (Appendix A)

These two interviewees were chosen because of the importance of ACIC in the Brazilian scenario, considering that this institution has been working since 1977 with free services for the blind and people with low vision. The combination of the preliminary theoretical review and the exploratory interviews resulted in the definition of the three categories of analysis Physical Evidence, Service Cycle, and Personal Interactions - used for the field research phase.

Once the objects of study and the research objectives of the exploratory phase were defined, the next step was to identify the possible sources for the triangulation of data, resulting in three data collection blocks: literature review and other relevant secondary data; participant observations and customer journey; and individual face-to-face interviews.

According to Creswell (2010, p.208), qualitative researchers often collect multiple forms of data, such as interviews, observations, and documents, rather than relying on a single source of data. Then the researchers examine all the data, make sense of them, and organize them into categories or themes that cover all data sources.

In addition to the aforementioned techniques, Customer Journey also acts as a complement to the data triangulation. According to Zomerdijk and Voss (2010), this technique involves identifying the activities and events related to the provision of a service from the perspective of the client. In the case of this research, it involved the experience of one of the researchers herself and her participant observation before the individual face-to-face interviews, thus reducing the impact of the interviewees' perceptions on the researcher's experience.

Customer Journey is considered one of the milestones in the service design process, used to understand how customers behave on a journey, what they are feeling, and what their motivation and attitude is throughout this process. It is a research tool which comes with the assumption that feeling what someone else feels is different from interpreting what someone else feels. In this sense, an observational protocol was elaborated regarding the customer journey in this research, highlighting in each stage the perceptions of the researcher, as well as the observations of the companion in relation to the situations experienced. According to Gray (2012), personal impressions and feelings can often be a useful source of analytical ideas at a later stage. Thus, the author states "write down everything you think about, including your feelings about events, people, conversations, and your interpretations of your emotional reactions" (Gray, 2012, p. 326).

The field research was undertaken with ten interviewees (six women and four men) that were selected using the snowball sampling technique, in which, according to Gray (2012, p. 127), "the researcher identifies a small number of subjects which, in turn, identify others in the population." Since ACIC's President and Technical Manager are considered by Gray (2012) to be "sources of knowledge," the indications given by them have sequenced data collection until a pattern of responses was identified. This pattern was obtained by the seventh interview and three more interviews were performed to confirm if the same critical points would keep coming up.

The interviewees' profile includes three people who have low vision, two with congenital blindness, two who lost their sight soon after birth, one who lost their sight during adolescence, one mother of a 12-year-old boy who has congenital blindness (she does not have visual impairment), and one Professor of Orientation and Mobility at ACIC with 14 years of experience in the habilitation and rehabilitation of people with disabilities, of which six years have been focused on people with visual impairment (he does not have visual impairment).

These two interviewees who do not have visual impairment were chosen because of their degree of daily involvement with the reality of visually impaired people. Therefore, these two 
interviews did not adopt the original interview protocol (Appendix B) as in the other interviews, but rather a survey of the perceptions of each one based on their experience (Appendix C), seeking to raise points contained in the original protocol.

The original interview protocol includes personal questions, such as to give a brief history of themselves, their lifestyle, and what services the interviewee usually uses; as well as questions related to service experience itself, as follow: What draws your attention when entering some environment/using a service? What makes you want to stay longer? What makes you want to leave? What do you dislike when experiencing a service? It is of the utmost importance to clarify that the three categories of analysis - Physical Evidence, Service Cycle, and Personal Interactions - were not mentioned by the researchers in the protocol in order to verify if they would be brought up naturally by the interviewees through these open and general questions.

To identify the Best and Worst Experiences in services in order to provide the basis for the proposed framework, the Critical Incident Technique (CIT) was adopted, since it is one of the most used tools in the field of service research for understanding factors of success and failure in consumers' perceptions. Advocated by Flanagan, CIT aims to retrieve from the interviewees' memories aspects that were outstanding during the service experience and that are reported in an open and spontaneous way (Edvardsson \& Roos, 2011; Gremler, 2004).

It is worth mentioning that the interviewees were also questioned about their own perspective on creating a service - If you were about to create a service such as (choose the one that was most mentioned), what points would be critical in your perception? - and what message they would like to give to service managers who wish to improve the service provided but do not know how to start.

The responses of the ten interviewees (identified here as I1 to I10) were recorded and transcribed, resulting in a total of ten hours and 46 minutes of talk time and 130 pages of transcripts
(A4 size, no spacing, font size 12). Literal transcription was adopted as the transcription level because it keeps the statements organized and facilitates the data analysis process (Gibbs, 2009)

As recommended by Hevner et al. (2004), the proposed framework was validated by the interviewees in order to guarantee its utility, quality, and efficiency.

\section{Results}

The research results begin with the description of the categories of analysis, highlighting the most recurrent subcategories in the data analysis and their relationship with the three initial categories. Subsequently, aspects in common narrated by the interviewees regarding the worst and best experiences are illustrated as two conceptual maps, relating them to the identified categories, which are highlighted in the text in italics.

\section{I Categories of analysis}

The analysis of the collected data allowed the creation of 32 subcategories of analysis, starting from the three initial ones - Physical Evidence, Service Cycle, and Personal Interactions. These 32 subcategories stood out from others. For example, the subcategory Communication had 165 citations and 13 links with other subcategories. This subcategory is part of the group that stands out from the general context, as happened with the subcategory Empathy (131 cit.; 7 links). Both subcategories - communication and empathy are part of the "Personal Interactions" category. Another subcategory that stands out is Attendance (108 cit.; 4 links), part of the "Service Cycle" category. This group represents almost a third of the total number of citations created, which highlights the importance of these subcategories for the interviewees.

Regarding the Physical Evidence, it was observed that the aspects mentioned are limited to the Normative Aspects, such as Accessibility/ Universal Design, Spatial Layout, and Signage. There was a clear need for redundancies in 
the signage that consider the five senses. In addition, assistive technology, which is also part of the normative aspects, plays an important role because some technological resources play the role of "seeing" the place or objects, making some experiences more fluid.

In relation to the Service Cycle, the relevance of enabling a Customized Flow according to the customer's profile was noted. In addition, the Initial Approach, Attendance, and Payment were identified as critical moments of truth regardless of the service segment reported. A direct relationship is observed between the aspects related to the service cycle and the personal interactions in the reports of the best experiences, which is the third category analyzed.

Among the subcategories regarding Personal Interactions, Communication and Empathy played a notable role, emphasizing how to put oneself in someone else's place. In addition, being aware of the messages transmitted through verbal and non-verbal communication makes a difference in the interactions in services. It can be stated, according to the interviewees, that this category has proved to be the main barrier for people with visual impairment, in many cases more so than the architectural barriers that are normally more discussed. The reasons that lead to this situation are partly the lack of interest in connecting with others, but a large part is due to lack of information, training, and prejudice. The interviewees report the existence of a stereotype regarding people with visual impairment, which includes being treated as incapable, being "invisible" (since people do not interact directly with those with disabilities, preferring to talk to their companion), being treated as a child, and being treated as if they had another type of disability.

\subsection{Reports on the worst experiences}

This topic indicates which aspects are related to the worst experiences when it comes to services, as well as reinforcing points to be avoided in some service segments. The Critical Incident Technique was used, through the questions "What was the worst experience you ever had with any service?" and "Is there a place you would not go back to ever again?”

Some respondents said that there was no specific situation:

do you know what is interesting? These bad things, they are so natural in our life that I have difficulty saying what is worse, or what was the worst of the worst (I9).

I'm not much for remembering the best or the worst because I just let it go (laughs) $[\ldots]$ at the time I get very angry but then I just let it go because I always think "it's not the first time and it won't be the last" and now you ask for the worst experience, I don't know if I'm going to know (I4).

Among the worst experiences reported were the services of supermarkets, schools, nightclubs, gyms, malls, and banks. Figure 2 illustrates a conceptual map of the worst experiences in services, highlighting the main factors related to the negative perceptions of the interviewees, which should be avoided by the service providers as much as possible. The results show that the concepts of Spatial Layout, Communication, and Initial Approach are the main causes of the Worst Experience. It is worth mentioning that Attendance (or absence of) is part of the causes of worst experiences and is directly associated with Communication. 


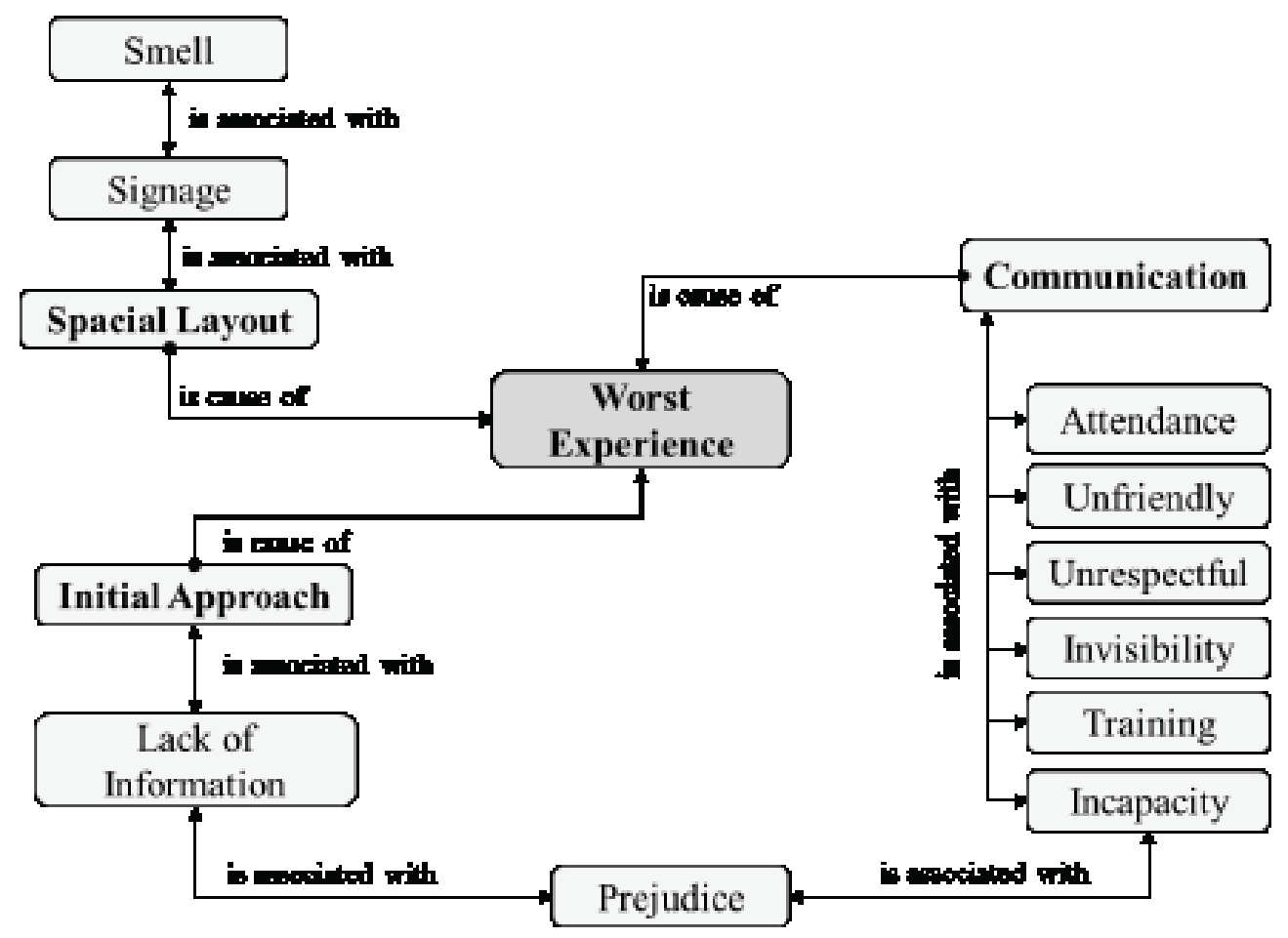

Figure 2. Conceptual map of the worst experiences in service.

The problems identified in the Initial Approach are associated with Lack of Information and ways to communicate, with failing to be Friendly and Respectful, treating the person with the disability as someone who is incapable (Incapacity), or an absence of communication (Invisibility) all featuring here. According to the interviews and the customer journey by one of the researchers, the various combinations of these factors during the Initial Approach result in negative experiences when it comes to service. The following excerpts illustrate the issue, describing a shopping experience in a supermarket and an experience related to visual impairment in a mall, both cases in Florianópolis:

the service by the employees isn't the best, you have to be lucky. Sometimes you find a very dynamic person, patient... there are others who serve you like they are almost dying and desperate for you to leave. For example, I asked "do you have this kind of meat?" "no, we don't" "but you didn't even look, you didn't even leave to verify, how do you know you don't have any?" Then he went there and they had it ... so, you have to impose yourself, you have to be kind of annoying, you know? This is bad ... it's bad (I7).

The following shows a combination of the Initial Approach with Invisibility:

(when) I arrive at an establishment with another person... it happened once to me, when I went to [name of the mall] with a security guard who was helping me, and then the attendant asked him "where is he going?" I was silent, she did not ask me... there was that silence... "Ah, where are you going?" [the attendant asked I9] Ah, it is improving... then I asked [her]... if she pulled a face at me, whatever, I cannot see, can I? (laughs) (I9).

It is worth emphasizing that Lack of Information is associated with Prejudice and the perception of Incapacity. In some cases, the relationship of these three factors combined with the Communication and Initial Approach results in embarrassing situations, as described below: 
I was in a public office and I wanted to go to the elevator... I don't think I was even dressed badly (laughs). I came in [to the reception desk] and said: "could you help me, please?" And the person said: "I have nothing to give" (laughter) (I4).

In addition to the Initial Approach, the combination of the factors in the subcategory Communication, previously mentioned together with the subcategory Attendance, also results in unpleasant situations. The following excerpts of the interviews highlight the absence of communication (Invisibility) and Attendance in experiences in two nightclubs near Florianópolis:

no one wanted to serve us, they left me and my friend at a table, alone. Where do we get drinks? So, we had to go around all the tables, [there was a lot of] people, nobody came, we had to keep asking [for assistance], everyone half intoxicated... oh, annoying, you know? (I10).

The combination of Lack of Information, Communication, and Attendance was used mainly to describe bad experiences and not only in cases of the worst experiences. Interviewee I3, when talking about an experience at a gym in Florianópolis, shows that the service provider does not always realize that they are not communicating in the best way:

I went to my first experimental class, and I came back from that class, crying with anger [...] first of all, my blindness is congenital, right? So, imitation does not work for me. There are movements that I do not know, I do not know how to do it $[\ldots](\mathrm{B}, \mathrm{I} 3)$

When questioned about the existence of an accompanying service when the visually impaired person arrives in the service environment with someone, some interviewees mentioned that "this service that should be done by the person working in a space is done by my companion" (I1), or "sometimes we always have to play this role of mediator. We are a client, the one who should do this should be the service provider" (I4). This was one of the main reasons for the terrible experience at a bank in Florianópolis, when a person with low vision was the companion of a blind person.

Regarding the physical aspects, two subcategories stand out: the presence of adequate Signage and the Spatial Layout of the service environment. Interviewee I7, for example, states "I see it this way, the bigger the place, the more shops, you know? The more complicated it seems to be" referring to the segment of supermarkets and department stores. For people with low vision this point is fundamental, since in some places, objects, lighting, and glass doors, for example, hinder the location and movement within the internal environment. In other situations, if the person has low vision and does not use a cane, some people doubt their disability and do not guide the client in the right way.

When it comes to Personal Interactions, training is a key point, according to the interviewees. One of the results of this training would be the creation of a Customized Flow, which was not mentioned during the reports on the worst experiences as a practice of the service provider, making evident the differential of applying this aspect in building the service cycle:

There was a point where he did not want to go to school: "Mom, I'm going to school to do what? Sit there listening?" Everyone reading, everyone writing, and he isn't. The teachers don't know what to do, you know? So it's a very complicated situation for them and for me as a mother (I6).

Finally, although the reports cite embarrassing and unpleasant situations, it is noted that most of the interviewees learned not to take some situations seriously, considering the number of times these situations happen: "in fact we have 
to see the funny side of the things that happen, because otherwise we would not leave the house because you never know what to expect when you leave alone" (I4).

\section{$4 \cdot 3$ Reports on the best experiences}

This topic highlights which aspects are related to the best experiences in service reported in the interviews, as well as pointing out good practices of some service segments. For this purpose, Flanagan's (1954) Critical Incident Technique was used, through the questions: "What was the best experience you ever had with any service? The one that positively marked you? What happened?"

Most of the interviewees pointed out at least one experience as strikingly positive, but mentioned how it was difficult to identify a significant positive experience to report: "The best? You will call me negative, but I'm not able to point out a place like that, there aren't any" (I5).

Of the best experiences reported, the services mentioned included malls, a farm hotel located near Florianópolis, nightclubs, an airline on a trip from Florianópolis to Espírito Santo (Brazil), and the internet - not with the provider specifically, but due to the possibility of accessing information provided through the internet.

Figure 3 illustrates the network of factors driving the good experiences, according to the interviewees, which could be used by service providers to understand which aspects should be addressed regularly when serving customers. The results show that the concept of Best Experience is directly associated with a Customized Flow created by the service provider to meet the customer's profile, as well as the Spatial Layout.

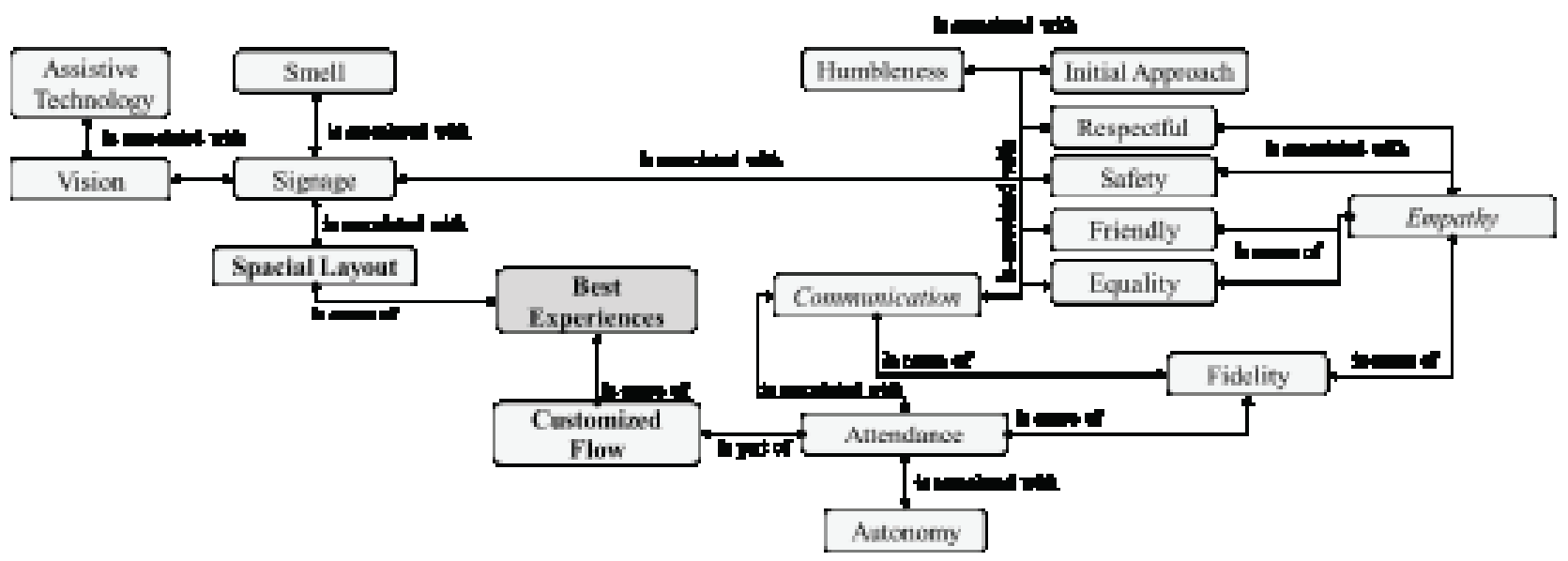

Figure 3. Conceptual map of the best experiences in service

Customized Flow encompasses the subcategory Attendance, which is directly associated with Communication and Empathy in service encounters. Empathy is still perceived as a factor that leads to the creation of a customized service cycle and being Friendly and Respectful in the way of communicating.

The care that the airline took with me. Because from the moment they see that you have a disability, they monitor you all the time, right? As you go to a VIP room, then when you go to the plane there is someone from the company [name of the airline]. There is someone who is with you all the time (I1).

In addition, the Humbleness present in the Communication during the Initial Approach was also a factor that stood out: "what gets my attention is service. When the person comes to 
assist you, when they come in such a way without stepping on eggshells because you are blind, you know? They come to help you with an open mind" (I4).

The feeling of Safety and tranquility that is transmitted through Attendance and Communication, as well as Signage, makes the experience more enjoyable and fluid.

All those who were with me here in Florianópolis, São Paulo, and Espírito Santo, all of them always gave me, both in and out, a lot of confidence to get on the plane, to sit down, and explained the things that I needed to know at the time (I1).

It is worth mentioning that although the flow is customized, there is a desire for Equality in relation to others and reinforcing this message can be a differential for the service provider. "For me, the best experience in this sense, [the one] that gave me wings and I thought 'my limitation is gone', was when I went on the internet for the first time" (I3). "The waiters also helped at the time of serving the food [at the farm hotel] [...] and during the horseback rides they would act with us as they had acted with other guests, I think" (I4).

Finally, Attendance, Customized Flow, Empathy, and Communication are directly associated with Fidelity and kindness in the reports on the experiences, making it clear that these aspects are present in the best experiences and, if perceived in others, not only impact positively, but also increase the chances of these customers returning.

It can be seen that according to the experiences reported, hedonic consumption is very important for this group of people who spontaneously narrated the most varied experiences, both daily and sporadic - although their experiences usually reflect the utilitarian aspect of even hedonic services more, thus making it possible to draw a parallel with the theory presented by Wakefield and Blodgett (1999), allocating the service segments mentioned by the interviewees according to Figure 4.

Intention of Consamption

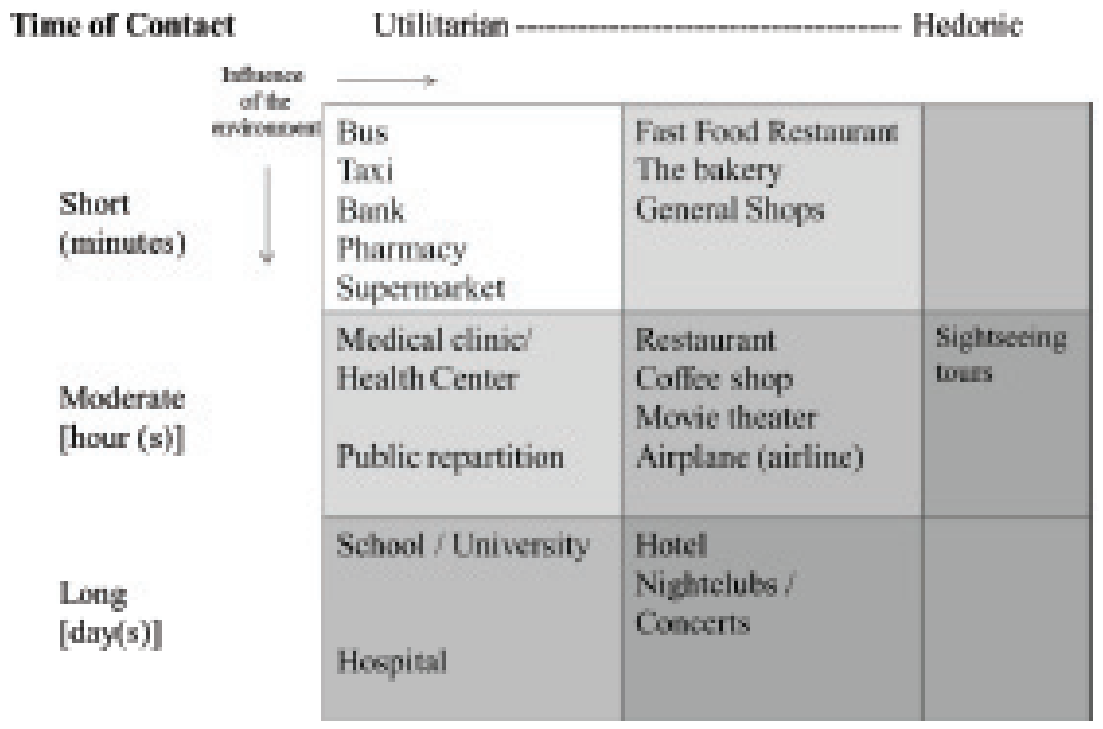

Figure 4. Typology of service environments cited by respondents 
Schmitt and Zarantonello (2013) believe that one of the hallmarks of the experience economy is precisely to provide memorable moments rather than just utilitarian and functional experiences, which is a great opportunity and strengthens the role of service experience management for this client profile.

It is important to emphasize that according to Gentile et al. (2007, p. 397), "this experience is strictly personal and involves the client's involvement at different levels (rational, emotional, sensorial, physical, and spiritual)," this being an "internal and subjective response that each client has in relation to any direct or indirect contact with a company" (Meyer \& Schwager, 2007 , p. 8). Therefore, the degree of importance given to the aspects raised in this study reflects the reality of the people involved in the research.

\section{Proposed Framework}

This section presents a proposal for a framework for service experience management from the perspective of people with visual impairment within the context of the Brazilian marketplace, thus meeting the objective of this research. The combination of Booms and Bitner's (1981) theory of the 3 Ps of Service Marketing (physical evidence, people, and processes) with the three propositions of Bolton et al. (2014) formed the backdrop to this proposal. To that end, it is worth mentioning that the principles adopted in this proposal follow the thinking of Stickdorn et al. (2010), who argue that service experience management needs to be user-centered, cocreative, be seen as a sequence of interrelated actions, make physical products evident, and be holistic.

Figure 5 illustrates the conceptual framework proposed for inclusive service experience management based on questions to mobilize the discussion whenever managing an existing service or creating a new one. The following five categories are contemplated: Consumption Profile, Physical Evidence, Service Cycle, Personal Interactions, and Types of Experience.

Of these five categories validated by the interviewees, two emerged from the literature review throughout the research process (Consumption Profile and Types of Experience) and the other three (Physical Evidence, Service Cycle, and Personal Interactions), which were previously found in the literature, were evidenced as fundamental aspects in the research process. It is worth mentioning that the worst and best experiences mentioned previously underpinned aspects to highlight and improve within a service and those to avoid, as shown in the framework. 


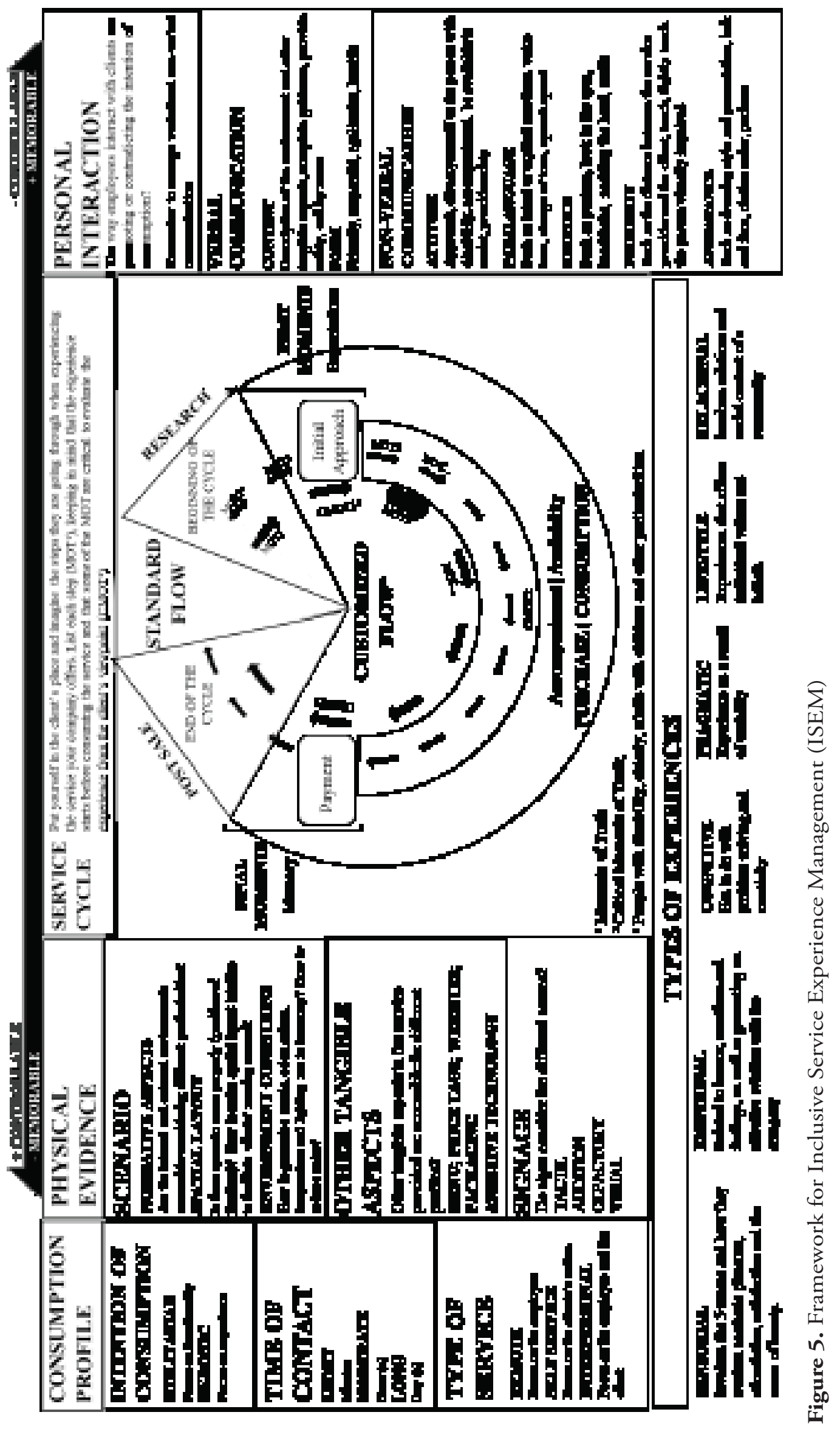


The first category, Consumption Profile, aims to identify parameters that help the experience creation and management. The first parameter is the Intention of Consumption of the service, showing whether it is Utilitarian, i.e. focused on functionality, or Hedonic, i.e. focused on experience. Contact Time is estimated to understand how much time the consumer dedicates to that experience in order to align customer expectations with the service cycle. These two parameters came from Wakefield and Blodgett's (1999) theories, as shown in topic 4.2 , and the third parameter, which refers to the Type of Service provided (remote, self-service, or interpersonal), is defended by Bitner (1992) as a way of aligning the customer's and the service provider's needs. If it is a remote service, the physical evidence related to the scenario applies primarily to employees, and the other tangible aspects tend to encompass the points of contact of the company with the client. In self-service, both the physical evidence and the service cycle should be focused on the actions of the clients, to make the experience fluid. These actions are also important in interpersonal services; however, the combination of the actions and needs of clients and employees is fundamental in this type of service.

The second category, Physical Evidence, emerged from Booms and Bitner (1981) and Bolton et al. (2014) and aims to support the project scenario and other tangible aspects involved in the service, so that it is thought of in an inclusive way. Note that within the Scenario, which borrowed from Bitner's (1992) scenario theory combined with specific aspects evidenced during the research process, the Normative Aspects are highlighted, emphasizing the universal design to meet the different customer profiles. In addition, it is essential to analyze if the Spatial Layout facilitates or hinders the service flow, in cases where the client is visually impaired, uses a wheelchair, is an elderly person, or is an adult with a child, for instance. Environmental conditions are also part of the projection of the scenario, since the noise level, odors, lighting, ambient music, and choice of colors are factors that directly influence the customers' willingness to remain in or to leave the service environment, in addition to facilitating or hindering the ability to move around the setting. It is worth mentioning that there is a clear need for redundancies in the signage that consider the five senses, according to the interviewees.

The third category, Service Cycle, encompasses the points of contact of customers with the company, from pre-sale to post-sale. This category embraces theories from Booms and Bitner (1981), Bolton et al. (2014), Gianesi and Corrêa (2010), Normann (1984), and Verhoef et al. (2009), as well as the primary data collected during the research process. This cycle aims to facilitate a visualization of the stages of the customer experience, highlighting the Standard Flow of activities and a Customized Flow, according to the customer's particularities. The main characteristic of the customized flow is its flexibility, and three Moments of Truth (MOT) were considered as "Critical Moments of Truth" (CMOT) during the data collection, which are common to different types of service and segments, as follows: Initial Approach, Attendance/Availability, and Payment. Therefore, it is paramount to pay special attention to these critical points of contact.

The fourth category, Personal Interactions, which is also inspired by Bolton et al. (2014) and Booms and Bitner (1981), combined with Sundaram and Webster (2000), draws attention to Verbal and Non-Verbal Communication during the customer experience, since empathic communication was identified as one of the differentiating elements of services, according to the data collected in this research. It is observed that Verbal Communication contains the transmitted Content and the Form in which the content is expressed. As for the Non-Verbal Communication, it contains the elements that send messages beyond what is said, such as Attitude, Paralanguage, and Kinetics when speaking, Proximity between the service provider and the customer, and Physical Appearance.

Finally, the fifth category refers to the Type of Experience, which adopted the types of experiences advocated by Gentile et al. (2007). The objective of this category is to encourage the 
conscious creation of different types of experience during the service delivery, considering both the consumption and customer's profile, in order to set the business apart from the usual utilitarian experiences highlighted during the research by the participants. It is worth mentioning that it is possible to work with more than one type of experience, generating a holistic combination that meets different profiles and creates memorable moments which have the power to build a loyal relationship between the service provider or brand and the customer.

Sensory experiences, for example, are formed of experiences involving the five senses and how they awaken aesthetic pleasure, stimulation, satisfaction, and a sense of beauty. Emotional experiences are related to humor, and feelings, and have the power to generate an affective relationship with the company. Cognitive experiences refer to problem solving and creativity, whereas Pragmatic experiences are observed when the consumption profile is Utilitarian, since those experiences are perceived as the result of usability. The experiences forming a Lifestyle include those affirming individual values and beliefs. Finally, the Relational experiences involve the relations and the social context of a community, such as local lunch or dinner events to raise donations for a local charity, for example.

Another feature of this framework is the degree of Control and Memory, represented as a line positioned on top of the Physical Evidence, Service Cycle, and Personal Interaction dimensions. According to Verhoef et al. (2009), this line shows that the customer experience is formed of controllable elements, such as Physical Evidence and part of the Service Cycle, and of less controllable or even uncontrollable elements such as Personal Interaction. The degree to which each category is positively remembered by the clients was based on the data collected.

The presence of this line in the framework has the role of highlighting the power of personal interactions and the need for managers to seek to positively influence these connections. However, it is important to emphasize that this scale is relativized between the three dimensions, i.e. being less memorable - as in the case of Physical
Evidence - does not mean it is less important or memorable than other elements not present in these three dimensions.

\section{Conclusion}

There are more than 7 billion people in the world. Each one features a unique combination of particularities, dreams, and challenges experienced every day. Of these, more than 285 million (4\%) have a common challenge: to live in a society that is often not prepared to receive them. Visual impairment affects more than 285 million people worldwide and the vast majority of the cases are concentrated in poor or developing countries, which is the case of Brazil (WHO, 2014a). Unfortunately, public and private services are hardly projected from an inclusion perspective in Brazil, which negatively impacts the lives of many people, including those with visual impairment.

Representing more than $60 \%$ of Brazil's GDP in the last two decades (IBGE, 2015), the service sector has a massive impact on society, not only in the economy itself, but also as a channel to change the mindset of the population in order to find new ways of creating business and strengthening social relationships and inclusion practices in the country. The importance of this subject is not reflected in the volume of scientific production on these issues, which presents a bigger challenge for business owners who need to make decisions to align themselves to the Brazilian Law on the Inclusion of Persons with Disabilities n. 13,146 (2015), which sought to ensure and promote conditions of equality regardless of the location.

Combined with the relevance of the service experience in the academic field, this scenario resulted in the present research, which sought to propose a framework to enhance the service experience from the perspective of visually impaired people and to contribute to reducing the gaps in the scientific production concerning social and service experience innovation paradigms. This proposal was supported by the data collected and the theoretical review conducted in this study.

The study behind this proposal was based on design science research and characterized as qualitative, using the respective methodological 
framework for technical collection and analysis. The research process included data triangulation, linking primary data collection to a literature review covering customer experience management, services marketing, and visual impairment. The combination of Booms and Bitner's (1981) theory of the 3 Ps of Service Marketing (physical evidence, people, and processes) with the three propositions of Bolton et al. (2014) formed the backdrop to this proposal. The data collected in the interviews confirmed the categories previously identified in the exploratory phase and allowed the inclusion of others, based on the interviewees' statements.

Finally, the data collected were coded in 32 subcategories of analysis, based on the connection between the three initial ones - Physical Evidence, Service Cycle, and Personal Interactions. Besides these 32 subcategories of analysis, 12 subcategories were created to highlight the service segment cited, to measure the relevance of the type of service for the interviewees, as well as to analyze specific aspects of the mentioned segments.

Given the inherent complexity of these principles, the proposed framework aims to simplify the use of this tool by service managers and to highlight the use of guiding questions within each category. In addition to promoting the debate, this strategy seeks to highlight important points that need to be considered, if the proposal is to manage service experiences in an inclusive way.

For this reason, the methodology adopted includes several service segments, creating the opportunity for further investigation in some specific sectors, which were strongly cited during the interviews, to understand if there are points not covered by the proposed framework, such as restaurants, shopping malls, supermarkets, department stores, and public transportation.

It is worth mentioning that there is a broad research field involving promoting well-being and equality through services, especially within the context of developing countries. Understanding how the other senses can be explored when creating an inclusive service, how to reduce stereotypes and prejudice in service experiences, up to what point laws reflect the real needs of impaired citizens within the service context, whether or not public services are inclusive and how to improve them, or how empathy can be improved internally in companies and reflected on the front lines, are all matters that can make an academic, social, and managerial contribution.

It is paramount to mention that theoretical frameworks which seek to insert social issues such as inequality in a developing country, such as Brazil, have different implications when compared to Northern countries, for example (Kerlin, Monroe-White, \& Zook, 2016). This premise is shared by Defourny and Nyssens (2016), who believe that such aspects cannot be analyzed using only models or approaches imported from North America or Europe, considering that the Brazilian context has its own cultural, social, economic, and other factors.

For this reason, the following topic has the intention of highlighting aspects from the proposed framework which have practical implications for businesses managed within the context of a developing country.

\section{I Managerial implications}

Considering that one of the roles of research on services is to provide knowledge and offer managers practical tools to improve the services provided, as well as the quality of life of employees and clients, this proposal represents a step toward the construction of inclusive services. It is noted that the highlights presented in the results as well as the framework itself can contribute in the field of management as a guide for those who wish to make their services more inclusive, but do not know how to start, stimulating not only service innovation, but also improving well-being through transformative services.

Working holistically on the five categories increases the chances of providing a hedonic experience for visually impaired customers, rather than only a functional one, which from a business perspective creates loyalty and increases the financial outcome.

The proposed framework can be used as a brainstorming, planning, or check list tool 
for new services in existing businesses or for the creation of a new business from scratch. All categories are related to each other, which means that the consumption profile for the service will directly impact on what kind of experiences could be provided; how the physical evidence needs to be thought about; what the standard service flow is and which options could be thought of as a customized flow for different needs; and how personal interactions will work within this experience, keeping in mind the company's culture and values, to plan how the verbal and non-verbal communication should promote all the aforementioned points.

Questions such as "Do signs consider the different senses?" or "Is there space to move properly? How could the spatial layout be made intuitive to enable clients to move around?" were included to raise awareness of redundancies in signage and the creation of inclusive scenarios, for example. In addition, the three critical moments of truth were highlighted in the Service Cycle - Initial Approach, Attendance/Availability, and Payment - to serve as a reminder that the whole experience satisfaction is highly influenced by these moments, which require special planning and attention in the service provision.

The study shows a high degree of unpreparedness in the service offer, when it is consumed by visually impaired people. Lack of empathy and communication were the most expressive problems in the interviewees' statements, and both are behind the recommendations presented in the Personal Interactions category. Although these points were also noted in studies within the North American or European context, it is worth emphasizing how important human interactions were seen as from the perspective of the participants of this research.

Brazilian culture highly values warmth in social interactions, which was one of the reasons why Personal Interactions stood out from the other categories, even with the gigantic abyss regarding accessibility all over the country in comparison with developed countries. Some aspects noted are also derived from the inner essence of human beings and were highlighted by Baker (2006), Baker et al. (2002), and Yu et al. (2015), such as the need for belongingness, equality, and independence, as well as the need to fight against stereotypes. To this end, team training is essential to prepare service providers to be more empathetic and consistent throughout the experience.

It was perceived in the field research that there is a strong need for this theme to be addressed as a way of modifying some cultural habits, demystifying visual impairment, and understanding that people with disabilities (and not disabled people) are human beings, above all else. There is no need for excessive pudency when establishing a relationship, but education and respect are required, knowing that some aspects are different. The stereotype that must be fought against includes:

a) being treated as incapable;

you go into the bank, the first question they ask you ... at least for me always ... most of the time it's like this, even when I go with someone [...] "ah, you came to receive your pension?”... "not yet, not yet" ... they still do not see the person as a person ... they see you as someone with a limitation and for that limitation only, right? As if we do not consume, no. (I3)

b) being "invisible", since people do not interact directly with those with disabilities, preferring to talk to their companion.

In the case of people with low vision, this aspect is even more evident, because despite having a low degree of acuity, it is still possible to see some things and movements. "I'm outraged at this part ... if you're asking 'can you help me?' the person keeps walking like 'I don't care because you will not see me"” (I10).

c) being treated as a child; talking through diminutive words, which is a specific resource of the Portuguese language used in Brazil;

d) and being treated as if they had another type of disability; 
It is perceived that in many cases there is a will to help or create something in an inclusive way, but the lack of knowledge regarding the specifics of each deficiency hinders this process, creating embarrassing situations, as mentioned by I8: "I am not deaf, I hear people talking and when people comment as if the person had not heard $\ldots$ it is very embarrassing ... several situations like this mess with the head" (I8).

This lack of knowledge can be filled by up-to-date guidelines regarding disabilities and personally asking for assistance from specialized institutions, inviting people with a disability to be part of the service design process, for example. Getting in contact with people who will use the service and listening to their own experiences is a simple way to not only connect the service provider to different profiles and form an inclusive mindset, but also create a meaningful work and service experience. In addition, the third pillar from Bolton et al. (2014) for meaningful change in the service experience, which could also impact on cultural habits, is precisely to co-create, to build together.

Finally, it can be said that simple and complex technologies can facilitate accessibility and increase social inclusion, but it is people with their worldviews and attitudes that make change happen. In addition, getting in touch with people to build something new is easier than imagined and more rewarding. Through the information gathered, it was perceived that working on these five categories in service management can make a difference and promote quality of life, education, respect for differences, autonomy of citizens (considering their particularities), equality, and inclusion.

\section{References}

Ando, B. (2008). A smart multisensor approach to assist blind people in specific urban navigation tasks. IEEE Transactions on Neural Systems and Rehabilitation Engineering, 16(6), 592-594.

Aken, J. E. Van (2004). Management research based on the paradigm of the design sciences: the quest for field-tested and grounded technological rules. Journal of Management Studies, 41(2), 219-246.
Aken, J. E. Van (2005). Management research as a design science: articulating the research products of mode 2 Knowledge Production in Management. British Journal of Management, 16(10), 19-36.

Aken, J. E. Van, \& Romme, G. (2009). Reinventing the future: Adding design science to the repertoire of organization and management studies. Organization Management Journal, 6(1), 5-12.

Albrecht, K. (1992). Revolução nos serviços: Como as empresas podem revolucionar a maneira de tratar seus clientes. São Paulo: Pioneira.

Baker, S. M. (2006). Consumer normalcy: Understanding the value of shopping through narratives of consumers with visual impairments. Journal of retailing, 82(1), 37-50.

Baker, S. M., Stephens, D. L., \& Hill, R. P. (2002). How can retailers enhance accessibility: Giving consumers with visual impairments a voice in the marketplace. Journal of Retailing and Consumer Services, 9(4), 227-239.

Bateson, J. E., \& Hoffman, D. K. (2001). Marketing de Serviços. Porto Alegre: Bookman.

Bitner, M. J. (1992). Servicescapes: The impact of physical surroundings on customers and employees. The Journal of Marketing, 56(2), 57-71.

Bitner, M. J., Ostrom, A. L., \& Morgan, F. N. (2008). Service blueprinting: a practical technique for service innovation. California Management Review, 50(3), 66-94.

Booms B. H., Bitner M. J. (1981). Marketing strategies and organization structure for service firms. In J. H. Donnelly \& W. R. George (Eds), Marketing of Services, Conference Proceedings. (pp.47-52). Chicago: American Marketing Association.

Bolton, N. R., Gustafsson, A., McColl-Kennedy, J., Sirianni, N. J., \& Tse, K. D. (2014). Small details that make big differences: A radical approach to consumption experience as a firm's differentiating strategy. Journal of Service Management, 25(2), 253-274. 
Conrad, B. (2016). Gestão da experiência em serviços: Framework a partir da ótica de pessoas com deficiência visual (Dissertação de Mestrado). Universidade do Estado de Santa Catarina, Florianópolis, SC, Brasil.

Creswell, J. W. (2010). Projeto de pesquisa métodos qualitativo, quantitativo e misto (3a ed.). Porto Alegre: Artmed.

Decreto-Lei n. 5.296, de 2 de dezembro de 2004. Regulamenta as Leis nos. 10.048 , de 8 de novembro de 2000, que dá prioridade de atendimento às pessoas que especifica, e 10.098, de 19 de dezembro de 2000, que estabelece normas gerais e critérios básicos para a promoção da acessibilidade das pessoas portadoras de deficiência ou com mobilidade reduzida, e dá outras providências. Retrieved from http://www. planalto.gov.br/ccivil_03/_Ato2004-2006/2004/ Decreto/D5296.htm

Defourny, J., \& Nyssens, M. (2016). Social enterprise and social entrepreneurship conceptions: What is at stake beyond discourses? BBE Newsletter für Engagement und Partizipation in Deutschland, $2016(5), 1-7$.

Dischinger, M., \& Jackson, J. M., Fº (2012). Can tactile tiles create accessible urban spaces?. Space and Culture, 15(3), 210-223.

Dischinger, M., \& Jackson, J. M., F'. (2006). Which future urban scenarios can we construct?. Management of Environmental Quality: An International Journal, 17(4), 409-420.

Dubé, L., \& Le Bel, J. (2003). The content and structure of laypeople's concept of pleasure. Cognition and Emotion, 17(2), 263-295.

Edvardsson, B., \& Roos, I. (2001). Critical incident techniques: Towards a framework for analysing the criticality of critical incidents. International Journal of Service Industry Management, 13(2), 251-268.

Faria, M. D., \& Motta, P. C. (2012). Pessoas com deficiência visual: Barreiras para o lazer turístico. Revista Turismo em Análise, 23(3), 691-717.
Faria, M. D., \& Silva, J. F. (2011). Composto para restaurantes: Atendendo consumidores com deficiência visual. Revista de Administração FACES, 10(1), 11-32.

Gardner, H., Kornhaber, M. L., \& Wake, W. K. (1998). Inteligência: Múltiplas perspectivas (M. A. Veronese, Trad.) Porto Alegre: Artmed.

Gentile, C., Spiller, N., \& Noci, G. (2007). How to sustain the customer experience: An overview of experience components that co-create value with the customer. European Management Journal, 25(5), 395-410.

Gianesi, I. G., \& Corrêa, H. L. (2010). Administração estratégica de serviços: Operaçóes para a satisfaçâo do cliente. São Paulo: Atlas.

Gibbs, G. (2009). Análise de dados qualitativos: Coleção pesquisa qualitativa. Porto Alegre: Artmed.

Gray, D. E. (2012). Pesquisa no mundo real. (R. C. Costa, Trad.) Porto Alegre: Penso.

Gregor, S., \& Hevner, A. R. (2013). Positioning and presenting design science research for maximum impac. MIS Quarterly, 37(2), 337-355.

Gremler, D. D. (2004). The critical incident technique in service research. Journal of Service Research, 7(1), 65-89.

Grönroos, C. (1998). Marketing services: The case of a missing product. Journal of Business \& Industrial Marketing, 13(4/5), 322-338.

Grönroos, C. (2009). Marketing: Gerenciamento e serviços. Rio de Janeiro: Elsevier.

Hevner, A. R., Salvatore, M. T., Park, J., \& Ram, S. (2004). Design science in information systems research. MIS quarterly, 28(1), 75-105.

Hirschman, E. C., \& Holbrook, M. B. (1982). Hedonic consumption: Emerging concepts, methods and propositions. The Journal of Marketing, 46(3), 92-101.

Holbrook, M. B., \& Hirschman, E. C. (1982). The experiential aspects of consumption: consumer 
fantasies, feelings, and fun. Journal of Consumer Research, 9(2), 132-140.

Instituto Brasileiro de Geografia e Estatístca. (2010). Sinopse do censo demográfico 2010. Retrieved from https://censo2010.ibge.gov.br/ sinopse/index.php?dados $=8$

Instituto Brasileiro de Geografia e Estatística (2015). Contas nacionais trimestrais. Retrieved from http://www.ibge.gov.br/home/estatistica/ indicadores/pib/pib-vol-val_201504_8.shtm.

Jutla, D. N., \& Kanevsky, D. (2009). wise Pad services for vision-, hearing-, and speech-impaired users. Communications of the ACM, 52(1), 64-69.

Kerlin J. A., Monroe-White, T. Zook, S. (2016). Habitats In The Zoo. In Young, D. R., Searing, E. A., \& Brewer, C. V. (Eds.). The social enterprise zoo: A guide for perplexed scholars, entrepreneurs, philanthropists, leaders, investors, and policymakers (Cap. 4, pp. 67-92). Northampton, MA: Edward Elgar Publishing.

Lacerda, D. P., Caulliraux, H. M., \& Spiegel, T. (2014). Revealing factors affecting strategy implementation in HEIs-a case study in a Brazilian university. International Journal of Management in Education, 8(1), 54-77.

Lacerda, D. P., Dresch, A., Proença, A., \& Antunes, J. A., Jr. (2013). Design Science Research: método de pesquisa para a engenharia de produção. Gestão \& Produção, 20(4), 741-761.

Lei n. 13.146, de 6 de julho de 2015. Institui a lei brasileira de inclusão da pessoa com deficiência (Estatuto da Pessoa com Deficiência). Retrieved from: http://www.planalto.gov.br/ ccivil_03/_ato2015-2018/2015/lei/113146.htm.

Levy, S. J. (1959). Symbols for sale. Harvard Business Review, 37(4), 117-124.

Levy, S. J. (1963). Symbolism and life style. Proceedings of American Marketing Association, 140-150.

Levy, S. J., \& Czepiel, J. (1974). Marketing and aesthetics. In S. J. Levy. Brands, Consumers,
Symbols, and Research (Cap. 8, pp. 84-102). Thousand Oaks, Calif. : Sage Publications

Lovelock, C. H. (1994). Productplus: How product + service. Michigan: McGraw-Hill.

Lusch, R. F., \& Vargo, S. L. (2014). Servicedominant logic: Premises, perspectives, possibilities. Cambridge: Cambridge University.

Moayeri, N., Mapar, J., Tompkins, S., \& Pahlavan, K. (2011). Emerging opportunities for localization and tracking. IEEE Wireless Communications, 18(2), 8-9.

Meyer, C., \& Schwager, A. (2007). Understanding customer experience. Harvard Business Review, 1-11. Retrieved from https://s3. amazonaws.com/ academia.edu.documents/35132402/FINAL_ HBR_Understanding_Customer_Experience. pdf?response-content-disposition=inline $\% 3 \mathrm{~B} \% 20$ filename\%3DUnderstanding_Customer_ Experience.pdf\&X-Amz-Algorithm=AWS4HMAC-SHA256\&X-Amz-Credential=AKI AIWOWYYGZ2Y53UL3A\%2F20190913 \%2Fus-east-1\%2Fs3\%2Faws4_request \&XAmz-Date $=20190913$ T $162721 \mathrm{Z} \& \mathrm{X}-\mathrm{Amz}-$ Expires $=3600 \& X-A m z-S i g n e d H e a d e r s=$ host $\& X-$ Amz-Signature $=8266651 \mathrm{~d} 9 \mathrm{fed} 58 \mathrm{c} 53423 \mathrm{f} 7242$ e333db96f558699fbc51936bef0ecf4d05cb9e4

Nasution, R. A., Sembada, A. Y., Miliani, L., Resti N. D., \& Prawono, D. A. (2014). The customer experience framework as baseline for strategy and implementation in services marketing. Procedia - Social and Behavioral Sciences, 148, 254-261.

Normann, R. (1984). Service management. New York: John Wiley \& Sons.

Norton, D. W., \& Pine, B. J. (2009). Unique experiences: Disruptive innovations offer customers more 'time well spent'. Strategy \& Leadership, 37(6), 4-9.

Ostrom, A. L., Bitner, M. J., Brown, S. W., Burkhard, K. A., Goul, M., Smith-Daniels, V., Rabinovich, E. (2010). Moving forward and making a difference: Research priorities for the science of service. Journal of Service Research, 13(1), 4-36. 
Ostrom, A. L., Parasuraman, A., Bowen, D. E., Patricio, L., \& Voss, C. A. (2015). Service research priorities in a rapidly changing context. Journal of Service Research, 18(2), 127-159.

Parasuraman, A., Zeithaml, V., \& Berry, L. (1988). Servqual: A multiple-item scale for measuring consumer perceptions of service quality. Journal of Retailing, 64(1), 12-40.

Pine, B. J., \& Gilmore, J. H. (1998). Welcome to the experience economy. Harvard Business Review, $76(4), 97-105$.

Pinto, M. R., \& Freitas, R. C. (2013). O que os olhos não veem o coração não sente? investigando experiências de compra por deficientes visuais no varejo de roupas. Revista de Gestão, 20(3), 387-405.

Sandnes, F. E., Tan, T. B., Johansen, A., Sulic, E., Vesterhus, E., \& Iversen, E. R. (2012). Making touch-based kiosks accessible to blind users through simple gestures. Universal Access in the Information Society, 11(4), 421-431.

Schmitt, B. H., \& Zarantonello, L. (2013). Consumer experience and experiential marketing: A critical review. Review of Marketing Research, 10, 25-61.

Shostack, G. L. (1977). Breaking free from product marketing. The Journal of Marketing, 41(2), 73-80.

Shostack, G. L. (1984). Designing services that deliver. Harvard Business Review, 62(1), 133-39.

Souza, A., Jr., \& Moraes, A. F. (2013). A cidade sob a ótica de quem vive na escuridão. Revista Pensamento Contemporâneo em Administração, $7(3), 156-172$.

Stickdorn, M., Schneider, J., Andrews, K., \& Lawrence, A. (2011). This is service design thinking: basics, tools, cases. Hoboken, NJ: Wiley.

Stock, R. M., \& Hoyer, W. D. (2005). An attitude-behavior model of salespeople's customer orientation. Journal of the Academy of Marketing Science, 33(4), 536-552.

Sundaram, D. S., \& Webster, C. (2000). The role of nonverbal communication in service encounters. Journal of Services Marketing, 14(5), 378-391.
Tsiros, M., Parasuraman, A. (2006). The anatomy of service encounter evaluations: a conceptual framework and research propositions. Asian Journal of Marketing, 12(1), 4-22.

Verhoef, P. C., Lemon, K. N., Parasuraman, A., Roggeveen, A., Tsiros, M., \& Schlesinger, L. A. (2009). Customer experience creation: determinants, dynamics and management strategies. Journal of Retailing, 85(1), 31-41.

Youngblood, S. A. (2013). Communicating web accessibility to the novice developer: From user experience to application. Journal of Business and Technical Communication, 27(2), 209-232.

Yu, D. X., \& Parmanto, B. (2011). US state government websites demonstrate better in terms of accessibility compared to federal government and commercial websites. Government Information Quarterly, 28(4), 484-490.

Wakefield, K. L., \& Blodgett, J. G. (1999). Customer response to intangible and tangible service factors. Psychology \& Marketing, 16(1), 51-68.

World Health Organization. (2014a). Visual impairment and blindness. Retrieved from: http:// www.who.int/mediacentre/factsheets/fs282/en/

World Health Organization. (2014b). Population Data by World Bank income group. Retrieved from http://apps.who.int/gho/data/view.main. POP2030.

Yu, H., Tullio-Pow, S., \& Akhtar, A. (2015). Retail design and the visually impaired: A needs assessment. Journal of Retailing and Consumer Services, 24, 121-129.

Zeithaml, V. A., Bitner, M. J., \& Gremler, D. (2014). Marketing de serviços: a empresa com foco no cliente. Porto Alegre: Bookman.

Zia, M. W. \& Fatima, F. (2011). Digital library services for visually impaired students: a study of the University of Karachi. Pakistan Journal of Library \& Information Science, 12 (1), 1-6.

Zomerdijk, L. G., \& Voss, C. A. (2010). Service design for experience-centric services. Journal of Service Research, 13(1), 67-82. 
Supporting Agencies: PROMOP - Santa Catarina State University

\section{Authors:}

1. Bibiana Conrad, Master's Degree in Business Administration, Santa Catarina State University, Florianópolis - Brazil. E-mail: bibianaconrad@gmail.com

ORCID

(iD) 0000-0001-9849-7120

2. Graziela Dias Alperstedt, Post Doctorate in Business Administration, FGV/EAESP, São Paulo - Brazil. E-mail: gradial@gmail.com

ORCID

(iD)0000-0003-0144-0406

3. Aline Regina Santos, PhD in Production Engineering, Santa Catarina Federal University, Florianópolis Brazil. E-mail: aline.santos@udesc.br

ORCID

(iD) 0000-0001-9116-9247

\section{Contribution of each author}

\begin{tabular}{|c|c|c|c|}
\hline Contribution & Bibiana Conrad & Graziela Dias Alperstedt & Aline Regina Santos \\
\hline 1. Definition of research problem & $\sqrt{ }$ & $\sqrt{ }$ & $\sqrt{ }$ \\
\hline $\begin{array}{l}\text { 2. Development of hypotheses or research questions } \\
\text { (empirical studies) }\end{array}$ & $\sqrt{ }$ & $\sqrt{ }$ & $\sqrt{ }$ \\
\hline $\begin{array}{l}\text { 3. Development of theoretical propositions } \\
\text { (theoretical work) }\end{array}$ & $\sqrt{ }$ & $\sqrt{ }$ & $\sqrt{ }$ \\
\hline 4. Theoretical foundation/ Literature review & $\sqrt{ }$ & $\sqrt{ }$ & $\sqrt{ }$ \\
\hline 5. Definition of methodological procedures & $\sqrt{ }$ & $\sqrt{ }$ & \\
\hline 6. Data collection & $\sqrt{ }$ & & \\
\hline \multicolumn{4}{|l|}{ 7. Statistical analysis } \\
\hline 8. Analysis and interpretation of data & $\sqrt{ }$ & & \\
\hline 9. Critical revision of the manuscript & & $\sqrt{ }$ & $\sqrt{ }$ \\
\hline 10. Manuscript writing & $\sqrt{ }$ & $\sqrt{ }$ & $\sqrt{ }$ \\
\hline 11. Other (please specify which) & & & \\
\hline
\end{tabular}

\section{Erratum}

Where was written:

"Review of Business Management, São Paulo, v.21, n.5, p.813-838, oct/dec. 2019."

Now read:

“Rev. Bras. Gest. Neg. São Paulo v.21 n.4 oct-dec. 2019 p. 813-838” 